\title{
Effective School Evaluation in Primary Schools from the dimension of Parents*
}

\author{
Durdağ 1 Akan ${ }^{1}$ \\ ${ }^{1}$ Educational Sciences, Educational Administration and Supervision, Faculty of Education, University of Atatürk, \\ Erzurum, Turkey \\ Correspondence: Durdağı Akan, Educational Sciences, Educational Administration and Supervision, Faculty of \\ Education, University of Atatürk, Erzurum, Turkey.
}

Received: November 20, 2016

Accepted: December 13, 2016 Online Published: December 21, 2016

doi:10.11114/jets.v5i1.2094

URL: http://dx.doi.org/10.11114/jets.v5i1.2094

*This article was written with the help of the published doctoral dissertation.

\begin{abstract}
The aim of this study is to analyze the effectiveness of the primary schools depending on "parents" dimension according to the perceptions of administrator and teacher in terms of different variables. It employed descriptive survey model. Data was collected through effective school questionnaire with the aim of determining the perceptions of school administrators and teachers working in primary schools in Erzurum. 155 school administrators and 616 teachers were selected through simple random sampling method and the obtained data was analyzed through arithmetic mean t-test, one -way analysis of variance (ANOVA). The data revealed that the school administrators and teachers expressed parents had a medium-level contribution to the effectiveness of primary schools. It is likely to state that school administrators and teachers in different duty stations and professional seniorities had different opinions about the attitudes of parents related to the effectiveness of schools while school administrators and teachers had similar opinions.
\end{abstract}

Keywords: effective school, parent, effectiveness

\section{Introduction}

School is an institution that meets the needs of individuals and prepares them for future. It influences the members of society and is influenced by them because of its function. Family, business world, non-governmental organizations are included in basic elements that surround school even both school and family are education environments for students (Şişman, 2002). School life consists of the relationships between teacher-student, teacher- teacher, student-student, teacher-family, child- family. The relationships in school are not restricted to formal education. It also involves multidimensional relations (Aydın, 2004). The studies indicate that the moral values and views about education of parents have a determinant factor on the success of student (Reynolds, 1985; Fullan, 1985)

Family is the core and basis of society. Child initially socializes in family. He mainly acquires his basic behaviors of his personality in family. These behaviors are highly difficult to change later. Family determines whether child grows in a compassionate and safe atmosphere. The members of family are related to each other with kinship and emotional ties. Therefore, family is an essential institution for individuals. Families have a dominant effect on children in preschool period. Family atmosphere has a significant effect on the personal development and independent identity acquisition of children (Başar, 1997; Yiğit \& Bayraktar, 2006; Akar, 2003).

The schools with high levels of academic success have environmental- parental support and involvement than the ones with low level of academic success. The study findings indicated that students have both higher levels of academic success and discipline providing that families have a closer relationship with schools. In addition, it is emphasized that the shortest way to determine the personal needs of student is to cooperate with family by supporting school and family cooperation (Çubukçu \& Girmen, 2006).

The active parental involvement in school activities has been an important focus of studies recently. The negative results caused by the isolation of parents from schools in a large extent and the tendency of parents to give school all responsibilities for child's education led this issue to come into prominence. The studies suggest that any kind of parental involvement in school activities have a positive effect on the success of student. The most effective parental 
involvement is to closely take care of child's education in both home and schools. Parents that read with their child, check his homework, help with his homework, find materials, meet teacher about his courses have the highest level of contribution to the child (Şişman \& Yücel, 2006; Yiğit \& Bayraktar, 2006)

Cooperation between school and parents plays an important role in enabling students to learn their rights, obligations and duties, acquire them as a behavior and have a higher level of success. It is highly necessary for school administrators and teachers to care about education of students not only at school but also at home and to consider parents as a part of school and education period. Parents are required to not to considers schools as an institution that provides public service and does not include themselves and to regard contribution to the education and success level of their children as a main task and responsibility as much as they can (Aydın, 2004).

Parents with higher levels of education background are observed to be more willing to involve in school activities and take responsibilities (Yiğit \& Bayraktar, 2006). The engagement of parents in school administration is likely to have a positive effect on the motivation of people in schools and their attitudes towards each other. Parents have the opportunity of being a source that school can benefit from and providing teachers with social and psychological support. They also have the chance of being more familiar with school and improving their own skills. They can be influential in embracing school and making the cold atmosphere of school friendlier. In addition, they can be responsible for problems outside school and lobbying. Lastly, they can be used as a volunteer staff in school of activities in case a need arises (Şişman \& Yücel, 2006).

Each school is single and unique although it has same basic functions. One of the indicators related to the quality of school is the feature of its being "effective" (Baştepe, 2002). New plans, policies and implementations enable schools to meet changing societal needs and transform them in a real sense (Cafoğlu, 1995).

Effective schools are required to firstly know the expectations of student and parents and continually improve cooperation among school-teacher-student-parent with the aim of realizing these expectations and increase the performance of students by this cooperation. Schools with higher level of academic success are observed to have more environmental, parental support and involvement than other schools. Literature findings and observation results related to the subject indicated that parents of schools that are provided with environmental support (Lezotte, 1989; Şişman \& Turan, 2004; Rosmiller \& John, 1983; Purkey \& Smith, 1983; Murnane, 1983; Turan, 2006; Good \& Brophy, 1986); often visit schools, share the aims of school, participate in decision-making process , try to solve the current problems in school, use their all strength for the interests of school, share their views and opinions about school with school staff, participate in social and cultural activities held in school, prepare a proper environment to enable student to effectively study and have knowledge about what school expect from them

The aim of this study is to analyze the effectiveness of primary schools depending on "parents" dimension according to the perceptions of administrator and teacher and to answer the following questions:

1. To which extent is the feature of being "effective" of primary schools depending on "Parents" dimension according to administrators and teachers working in primary schools?

2. Is there a significant difference between administrators and teachers' perception in primary schools?

3. Is there a significant difference between the views of administrators and teachers working in primary school institutions about the effectiveness of primary schools depending on "parents" dimension in terms of their gender, duty stations and professional seniorities?

\section{Method}

\subsection{Model}

This study was conducted through a descriptive survey model. Descriptive survey models are approaches that aim to literally describe a current or past case. A case subject or object of the study is aimed to be described as it is or in their own conditions. The study does not aim to change and influence them in a way (Karasar, 2002).

This study was carried out through survey model and aimed to determine the views of administrators and teachers about effectiveness depending on "Parent" dimension and investigated if there was difference depending on different variables.

\subsection{Population and Sample}

The population of the study consisted of 202 school administrators and 4083 teachers working in primary schools (except the ones with multigrade classes) in Erzurum. Sampling was not employed to choose school administrators in these schools, 800 samples out of teachers were chosen by simple random sampling method. 


\subsection{Data Collecting Tools}

Within the scope of this study, questionnaire was employed as a data collection tool with the aim of determining the views of teachers and school administrators working in primary schools in Erzurum. Data collection tool was developed through a literature review by studying related book, articles, thesis and other resources. Questionnaires previously used in "effective School "studies (Balc1, 2002, Şişman, 2002 et al.) were used. The views of school administrators, teachers and inspectors were received and expert opinion was consulted. Before putting the questionnaire into final form, it was applied to 42 school administrators and teachers in total and drawbacks that were observed in this pilot scheme, critics and recommendations were taken into consideration and the questionnaire was finalized. The internal consistency reliability of single factor scale was calculated through Cronbach's Alpha coefficient. The statistical analysis results in this study revealed that total internal consistency coefficient of scale was .97.

Data collection instrument that was applied to school administrators and teachers consists of 2 sections. There are 9 articles that involve personal information in personal information and "parent" dimension of effective school in the second section. In literature, there are 6 dimension including school administrator, teacher, student, school culture, learning environment and parent (Çubukcu \& Girmen, 2006, Yılmaz, 2006; Balc1, 2002; Şişman, 2002; Koçak \& Helvac1, 2011 ). The articles were prepared in accordance with Likert scale and consisted of advisory statements. Possible answers of participants related to these statements were divided into five categories and these categories were "strongly agree", "agree", "neither agree nor disagree", "disagree, "strongly disagree" and scores were 5,4,3,2,1 from the most chosen option to the least chosen one.

Questionnaires have been conducted in the primary schools in Erzurum city centre, its counties, towns, and villages. In this context, all of 202 school managers have been included in the scope of survey. Of the questionnaires sent to these managers, 167 have been returned, and after eliminating deficient and empty ones, the remaining 155 questionnaires have been evaluated. 4083 teachers, in total, working in these schools, have constituted the main body of the survey. Selected randomly regarding the numbers of the teachers in each school, 800 teachers, in total, have been sent questionnaires and 655 of these have been returned. Deficient and empty questionnaires have been eliminated and then 616 have remained. So, the rate of $\alpha$ and $d$ error in the survey has been reduced on a lower level.

Table: 1 . The numbers of the conducted and evaluated questionnaires

\begin{tabular}{lcccc} 
& & $\begin{array}{c}\text { The Number of Conducted } \\
\text { Questionnaires }\end{array}$ & $\begin{array}{c}\text { The Number of Evaluated } \\
\text { Questionnaires }\end{array}$ \\
\cline { 2 - 5 } & & 167 & $7 \mathrm{~F}+148 \mathrm{M}:$ & 55 \\
Teachinistrators & 202 & 655 & $333 \mathrm{~F}+283 \mathrm{M}:$ & 616 \\
\hline
\end{tabular}

\subsection{Data Analysis}

In the survey, arithmetic means have been examined in order to determine the perception levels of the managers and the teachers, and t-test has been made to determine if there is a statistical discrepancy between the managers' and the teachers' perceptions in terms of gender variables, and in the comparison made for the variables of professional seniority and place of duty, one-way variance analysis (ANOVA) has been used. Significance level has been taken as 0.005. To determine the groups between which consequential significant discrepancies are, Sheffe test has been used.

\section{Findings}

In this section, findings and comments have been given that obtained from analysis of the data collected for the purpose of the research.

Table 2. Administrators' and Teachers' Perceptions of Parental Aspect of Effective School

\begin{tabular}{lcc}
\hline Assumptions & Manager & Teacher \\
\hline In this school, parents; & $\bar{X}$ & $\bar{X}$ \\
\hline 1- often visit school. & 3,12 & 2,72 \\
2- share the goals of schools. & 3,05 & 2,60 \\
3- agree on the decisions about the school. & 3,13 & 2,85 \\
4- strive to solve the existing problems of the school. & 3,04 & 2,63 \\
5- use their existing power for the goals of the school. & 3,00 & 2,57 \\
6- can share their opinions on the school with the school personnel. & 3,20 & 2,97 \\
7- join social and cultural activities held in the school. & 3,40 & 3,00 \\
8- prepare an environment for the students to study effectively. & 3,01 & 2,68 \\
9-have information about what the school expect them to do. & 3,30 & 2,79 \\
\hline
\end{tabular}

According to the managers, the highest manager perception level on the basis of the articles is for the article "join social and cultural activities held in the school" $(\bar{X}=3.40)$ while the lowest is for the article "use their existing power for the goals of the school" $(\bar{X}=3.00)$.

According to the teachers, the highest teacher perception level on the basis of the articles is for the article "join social 
and cultural activities held in the school" ( $\bar{X}=3.00)$ while the lowest is for the article "strive to solve the existing problems of the school" ( $\bar{X}=2.57$ ). According to the acquired data, both participant groups think the student parents to have medium-level contribution to the effectiveness of the school.

Table 3. The comparison of the administrators' and the teachers' perception level regarding the parents in the effectiveness of the school (t-Test)

\begin{tabular}{llccccc}
\hline & Variables & $\mathrm{N}$ & $\bar{X}$ & $\mathrm{ss}$ & $\mathrm{t}$ & $\mathrm{P}$ \\
\hline Duty & Administrators & 155 & 3.14 & 0.847 & 4.64 & $.000^{*}$ \\
& Teacher & 616 & 2.76 & 0.933 & & \\
\hline
\end{tabular}

\footnotetext{
$* \mathrm{P}<0.05$ significance level
}

There is a statistically significant discrepancy between the managers' and the teachers' perception levels with regard to the parents $(p=0.000)$. Considering the arithmetic mean of the managers' and the teachers' perception levels of the degree that the primary schools in Erzurum have the features of an effective school in terms of "parents", the perception level of the managers is $\bar{X}=3.14$, and that of the teachers is $\bar{X}=2.76$, and it is clear that the perception level of the teachers is lower than that of the managers. The managers and the teachers think that the parents' attention is not on a sufficient level. That the school environment's and the parents' attention are not on a sufficient level will unavoidably affect the effectiveness of the schools negatively.

Table 4. The comparison of the administrators'perception levels of the gender variable ( $\mathrm{t}$ - Test)

\begin{tabular}{llccccc}
\hline Administrators & Variables & $\mathrm{N}$ & $\bar{X}$ & ss & $\mathrm{t}$ & $\mathrm{P}$ \\
\hline Gender & Male & 148 & 3.13 & 0.855 & & \\
& Female & 7 & 3.36 & 0.681 & 0.69 & 0.486 \\
\hline
\end{tabular}

$$
* \mathrm{P}<0.05
$$

When the table 4 is analysed, there is a significant discrepancy between the administrators' perception level of parent in terms of gender variable ( $p>0.486, t=0.69)$. Considering the arithmetic mean of the administrators' perception in terms of gender variable, the perception level of the male administrators is $\bar{X}=3.13$ and that of the female administrators is $\bar{X}=3.36$.

Table 5. The comparison of the managers' perception level regarding the place of duty variable (ANOVA)

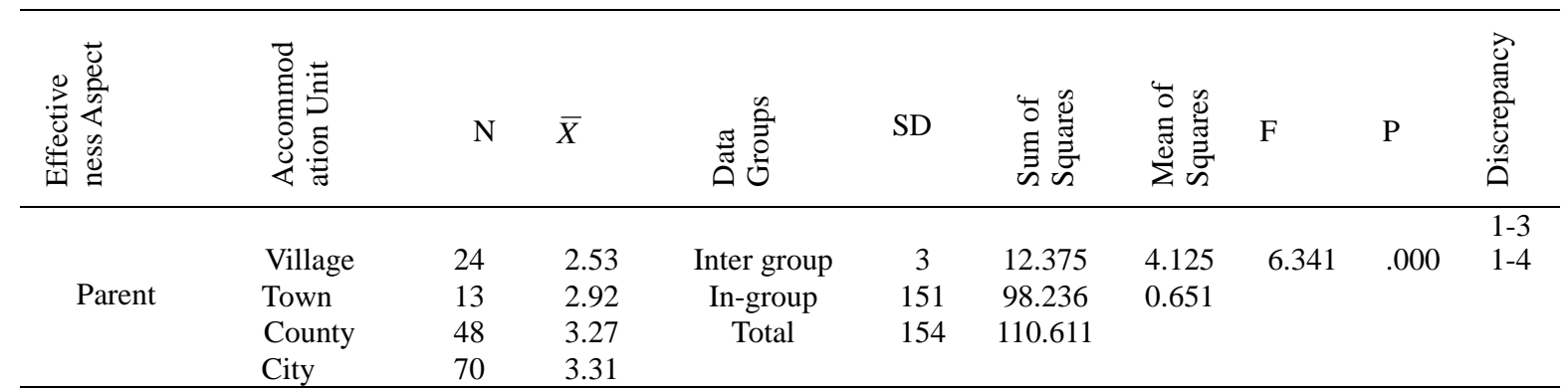

* $\mathrm{P}<0.05$

When the table 5 is analyzed, it is seen that the discrepancy between the scores is significant $(\mathrm{F}=6.341, \mathrm{P}<.05)$ according to the result of one-way ANOVA made for determining whether the managers', participating in the survey, perceptions of parental aspect of effective school change significantly with regard to the duty place variable. In other words, the managers participating in the survey change their perceptions of parental aspect of effective school significantly according to their place of duty. According to results of the Sheffe test made for finding the groups which have discrepancies between the duty places, it is understood that the significant discrepancy between the groups is between the perception levels of the managers in Group 1 Village primary schools and the perception levels of the managers in Group 3 and 4 county and city primary schools. 
Table 6 . The comparison of the managers' perception level regarding professional seniority variable (ANOVA)

\begin{tabular}{|c|c|c|c|c|c|c|c|c|c|c|}
\hline $\begin{array}{l}\text { Effectiveness } \\
\text { Aspect }\end{array}$ & $\begin{array}{l}\text { Professional } \\
\text { Seniority }\end{array}$ & $\mathrm{N}$ & $\bar{X}$ & $\begin{array}{l}\text { Data } \\
\text { Groups }\end{array}$ & SD & $\begin{array}{l}\text { Sum of } \\
\text { Squares }\end{array}$ & $\begin{array}{l}\text { Mean of } \\
\text { Squares }\end{array}$ & $\mathrm{F}$ & $\mathrm{P}$ & Discrepancy \\
\hline \multirow{8}{*}{ Parent } & & & & & & & & \multirow{8}{*}{12.369} & \multirow{8}{*}{$.000 *$} & $1-2$ \\
\hline & & & & & & & & & & $1-3$ \\
\hline & $1-5$ & 15 & 2.09 & Intergroup & 4 & 27.435 & 6.859 & & & $1-4$ \\
\hline & & & & & & & & & & $1--5$ \\
\hline & $6-10$ & 26 & 3.00 & \multirow{4}{*}{$\begin{array}{l}\text { In-Group } \\
\text { Total }\end{array}$} & 150 & 83.176 & \multirow[t]{4}{*}{0.555} & & & $2-4$ \\
\hline & $11-15$ & 22 & 2.96 & & 154 & 110.611 & & & & $3-4$ \\
\hline & $16-20$ & 19 & 3.78 & & & & & & & \\
\hline & $21+$ & 73 & 3.30 & & & & & & & \\
\hline
\end{tabular}

* $\mathrm{P}<0.05$

When the table 6 is analyzed, it is seen that the discrepancy between the scores is significant $(\mathrm{F}=12.369, \mathrm{P}<.05)$ according to the result of one-way ANOVA made for determining whether the managers', participating in the survey, perceptions of parental aspect of effective school change significantly with regard to professional seniority variable. In other words, the managers participating in the survey change their perceptions of parental aspect of effective school significantly with regard to their professional seniority. According to results of the Sheffe test made for finding the groups which have discrepancies between their professional seniorities, it is understood that the significant discrepancy between the groups is between the perception levels of the managers in Group 1 which has 1-5-year professional seniority and the perception levels of the managers in Group 2, 3, 4, and 5 which have 6-10-year professional seniority and also between the perception levels of the managers in Group 2 and 3 which have 6-10-year and 11-15-year professional seniority and the perception levels of the managers in Group 4 which has 16-20-year professional seniority. Therefore, it can be said the professional experience to be an important determinant of perception level.

Table7. The comparison of the teachers' perception levels of the gender variable ( $\mathrm{t}$ - Test)

\begin{tabular}{llllllc}
\hline Teacher & Variables & $\mathrm{N}$ & $\bar{X}$ & $\mathrm{SD}$ & $\mathrm{t}$ & $\mathrm{P}$ \\
\hline Gender & Male & 333 & 2.74 & 0.924 & 228 & \multirow{2}{*}{0.699} \\
& Female & 283 & 2.77 & 0.945 & & \\
\hline
\end{tabular}

* $\mathrm{P}<0.05$ significant level

When the table 7 is analysed, there is a significant discrepancy between the teachers' perception level of effective school in terms of gender variable ( $p>005)$. It can be said that gender is not an effective variable for the teachers' perceptions.

Table 8. The comparison of the teachers' perception levels of the duty place variable (ANOVA)

\begin{tabular}{|c|c|c|c|c|c|c|c|c|c|c|}
\hline $\begin{array}{l}\text { Effective } \\
\text { ness } \\
\text { Aspect }\end{array}$ & $\begin{array}{l}\text { Accommodation } \\
\text { Unit }\end{array}$ & $\mathrm{N}$ & $\bar{X}$ & $\begin{array}{l}\text { Data } \\
\text { Groups }\end{array}$ & SD & $\begin{array}{l}\text { Sum of } \\
\text { Squares }\end{array}$ & $\begin{array}{l}\text { Mean of } \\
\text { Squares }\end{array}$ & $\mathrm{F}$ & $P$ & Discrepancy \\
\hline \multirow[t]{4}{*}{ Parent } & Village & 24 & 2.23 & Inter group & 3 & 40.346 & 13.449 & 16.607 & $.000 *$ & $\begin{array}{l}1-3 \\
1-4 \\
2-4\end{array}$ \\
\hline & Town & 13 & 2.53 & In- group & 612 & 495.609 & 0.810 & & & \\
\hline & County & 48 & 2.77 & Total & 615 & 535.955 & & & & \\
\hline & City & 70 & 2.98 & & & & & & & \\
\hline
\end{tabular}

$* \mathrm{P}<0.05$

When the table 8 is analyzed, it is seen that the discrepancy between the scores is significant $(\mathrm{F}=16.607, \mathrm{P}<.05)$ according to the results of one-way ANOVA made for determining whether the teachers', participating in the survey, perceptions of parental aspect of effective school change significantly with regard to the duty place variable. In other words, the teachers participating in the survey change their perceptions of parental aspect of effective school significantly with regard to their duty place. According to results of the Sheffe test made for finding the groups which have discrepancies between their duty places, it is understood that the significant discrepancy between the groups is between the perception levels of the teachers in Group 1 village primary school and the perception levels of the teachers in Group 3 and 4 county and city primary schools and also between the perception levels of the teachers in Group 2 town primary schools and the perception levels of the teachers in Group 4 city primary schools. The Sheffe test made for determining the reason of this discrepancy has shown that there is a significant discrepancy between the teachers', working in city centre and in rural areas, perceptions of effective school in terms of duty place. Especially, that the need for teachers in rural areas is not met can be listed among the factors affecting the teachers' perception. 
Table 9. The comparison of the teachers' perception levels of professional seniority (ANOVA)

\begin{tabular}{|c|c|c|c|c|c|c|c|c|c|c|}
\hline $\begin{array}{l}\text { Effectiveness } \\
\text { Aspect }\end{array}$ & $\begin{array}{l}\text { Profes } \\
\text { sional } \\
\text { Senior } \\
\text { ity }\end{array}$ & $\mathrm{N}$ & $\bar{X}$ & $\begin{array}{l}\text { M Data } \\
\text { Groups }\end{array}$ & $\mathrm{SD}$ & $\begin{array}{l}\text { Sum of } \\
\text { Squares }\end{array}$ & $\begin{array}{l}\text { Mean of } \\
\text { Squares }\end{array}$ & $\mathrm{F}$ & $\mathrm{P}$ & Discrepancy \\
\hline \multirow[t]{8}{*}{ Parent } & & & & & & & & & & $5-1$ \\
\hline & & & & & & & & & & $5-2$ \\
\hline & $1-5$ & 325 & 2.52 & Intergroup & 4 & 51.991 & 12.998 & 16.410 & $0.000 *$ & $5-3$ \\
\hline & & & & & & & & & & $5-4$ \\
\hline & $6-10$ & 160 & 2.90 & In-Group & 611 & 483.964 & 0.792 & & & \\
\hline & $11-15$ & 78 & 3.04 & Total & 615 & 535.955 & & & & \\
\hline & $16-20$ & 25 & 3.06 & & & & & & & \\
\hline & $21+$ & 28 & 3.64 & & & & & & & \\
\hline
\end{tabular}

When the table 9 is analyzed, it is seen that the discrepancy between the scores is significant $(\mathrm{F}=16.410, \mathrm{P}<.05)$ according to the results of one-way ANOVA made for determining whether the teachers', participating in the survey, perceptions of parental aspect of effective school change significantly with regard to the professional seniority variable. In other words, the teachers participating in the survey change their perceptions of parental aspect of effective school significantly with regard to their professional seniority. According to results of the Sheffe test made for finding the groups which have discrepancies between their professional superiorities, it is understood that the significant discrepancy between the groups is between the perception levels of the teachers in Group 5 which has 21 -year or over professional superiority and the perception levels of the teachers in Group 1,2,3, and 4 which have respectively 1-5-year, 6-10-year, 11-15-year, and 16-20-year professional superiority. The more the teachers have professional superiority, the more they think the schools are more effective.

\section{Conclusion and Discussion}

The school managers and the teachers think that the parents make a medium-level contribution to the effectiveness of the school. The school environment and the parent aspect are among the aspects perceived on the lowest level in the studies concerning the effective school (Lezotte, 1989; Baștepe, 2002; Keleş, 2006; Cubukcu \& Girmen, 2006, Y1lmaz, 2006; Balc1, 2002; Şişman, 2002; Koçak \& Helvac1, 2011; Şahin, 2011; Toprak, 2011; Gündüz, 2015). That the level of the school envirenment and the parent attention is not on a sufficient level shows that the parents are less active in the teaching process. The parents' not being well-informed about what the school expects them to do might be a reason for this. Naturally, the effectiveness of the school gets affected negatively by this situation.

According to the findings, the managers and the teachers agree on the parents' attitude in terms of the effectiveness of the school. As for the professional seniority and the duty place, the managers and the teachers think differently. It can be say that the duty place and the professional seniority are significant determinants of the perception levels of the managers and the teachers. A lot of studies on this subject support these findings (Balc1, 2002; Şişman, 2002; Yılmaz, Oral, 2005; 2006; Çubukcu \& Girmen, 2006; Çobanoğlu, 2008; Gökçe \& Kahraman, 2010; Koçak \&Helvacı, 2011, Kaya, 2015).

The school environment and the parent attention, having an important place in the effectiveness of schools, need new understandings and practices to be on a sufficient level. In this sense, to improve the "parental" aspect, the school managers and the teachers need to be more active, to have effective communication with the families, and to have necessary knowledge and skills for these. Within this context, the school managers and the teachers have important duties.

\section{References}

Akar, İ. (2003). Factors of affecting student behavior (Classroom management, Edt: Zeki Kaya), Ankara: Pegem Publications

Aydın, İ. (2004). School - environment associations (Education and school management, Ed: Yüksel Özden, Ankara: Pegem Publications.

Balc1, A. (2002). Effective school / school development, Ankara: Pegem Publications.

Başar, H. (1997). Classroom management, Ankara: Pegem Publications.

Baştepe, İ. (2002). The School effectiveness perceptions of administriators, teacher and the eighth grade students in public normal and transported elementary schools, Unpublished PhD Thesis, Ankara University, Institute of Social Sciences, Ankara. 
Cafoğlu, Z. (1995). Empowerment of Schools, Education Management in Theory and Practice, 1(4), 449-555.

Çobanoğlu, F. (2008). Organizational identity and organizational effectiveness in primary education schools (sample of Denizli province). Unpublished PhD Thesis, Hacettepe University, Institute of Social Sciences, Ankara.

Çubukçu, Z., \& Girmen, P. (2006). Degree of Secondary education institutions of effective school characteristics: Journal of Social Sciences, 16.

Fullan, M. (1985). Change processes and strategies at the local level, Elenementary School Journal, 85(3), 391-422. https://doi.org/10.1086/461411

Gökçe, F., \& Kahraman, P. B. (2010). Components of effective school, Uludağ University, Education Faculty jurnal, XXIII(1), 173-206.

Good, T. L., \& Brophy, J. E. (1986). School effects. In M.C. Wittrock (ed.), handbook of research on teaching, 3rd Ed., New York: Macmillian.

Gündüz, S. (2015). Improving effective school according to the views of school sharers, Unpublished Master Thesis, Hasan Kalyoncu University, Institute of Social Sciences, Gaziantep.

Karasar, N. (2002). Scientific research method, Ankara: Nobel Publications.

Kaya, Y. (2016). Effective school development according to the views of school sharers (The case of Şahinbey), Unpublished Master Thesis, Hasan Kalyoncu University, Institute of Social Sciences, Gaziantep.

Keleş, B. (2006). Teachers' opinions on to what extend primary schools posses effective school properties (Çorum city sample),Unpublished Master Thesis, Gazi University, Institute of Social Sciences, Ankara.

Koçak, F., \& Helvac1, M. A. (2011). The effectiveness of school administrators, Education Science Research Journal. V. 1.

Lezotte, L. W. (1989). School improvement based on the effective schools resarch, International Journal of Educational Reasarch, 13, 815-824. https://doi.org/10.1016/0883-0355(89)90031-1

Murnane, R. J. (1983). Quantitative studies of effective school-what have we learned? (school finance and school improvement Ed: Odden A;WEEB D.L.), Ballınger Publıshıng Company, Cambridge, Massachusetts.

Oral, Ş. (2005). The assesment of primary schools from the angle of effective school consept (The example of Batman city), Unpublished Master Thesis, Dicle University, Institute of Social Sciences, Diyarbakır.

Purkey, S., \& Smith, M. (1983). Effective Schools Resarch, A Review Elementary School Journal, 83, 427-452. https://doi.org/10.1086/461325

Reynolds, D. (1985). Introduction: Ten years on-a dacade of reasearch and activity in schools effectiveness reviewed (Studying School Effectiveness Ed: David Raynolds) The Falmer Pres, London and Philaelphia.

Rosmiller, R., \& John, E. (1987). Resarch on Effective Schools: Implications for Less Developed Conries, Comparative Education Revive, 31(3), 377-401.

Şahin, M. (2011). Teacher perceptions about effective school and parent reletion, Unpublished Master Thesis, Maltepe Üniversitesi, University, Institute of Social Sciences İstanbul

Şişman, M. (2002). Search of excellence in education (Effective Schools), Ankara: Pegem Publications

Şişman, M., \& Turan, S. (2004). Education and school management, (Edt: Yüksel Özden), Ankara: Pegem Publications.

Şişman, M., \& Yücel C. (2006). Cooperation of parent school community, (Lecture Notes of School Administration Development Program), MEB General Directorate of Primary Education, Ankara.

Toprak, M. (2011). Primary school teachers' views on school effectiveness: Case of Adiyaman province, Unpublished Master Thesis, Firat University, Institute of Social Sciences, Elazı $\breve{g}$

Yiğit, B., \& Bayraktar, M. (2006). School-environment relations, Ankara: Pegem Publications.

Yılmaz, V. (2006). Degree of primary school's of effective school characteristics: Düzce case, Unpublished Master Thesis, Izzet Baysal University, Institute of Social Sciences, Bolu.

\section{Copyrights}

Copyright for this article is retained by the author(s), with first publication rights granted to the journal.

This is an open-access article distributed under the terms and conditions of the Creative Commons Attribution license which permits unrestricted use, distribution, and reproduction in any medium, provided the original work is properly cited. 